
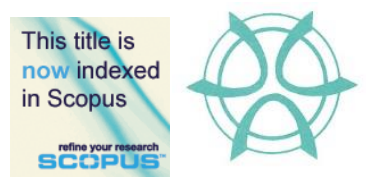

PLANNING MALAYSIA:

Journal of the Malaysian Institute of Planners

VOLUME 15 VOLUME 1 (2017), 333 - 346

\title{
MODELLING WILLINGNESS TO PAY FOR IMPROVED PUBLIC TRANSPORT SERVICES: THE CHALLENGES OF NON-RESPONSE TO STATED PREFERENCE HYPOTHETICAL QUESTIONS
}

\author{
Syahriah Bachok ${ }^{1}, \&$ Zakiah Ponrahono ${ }^{2}$ \\ ${ }^{1}$ Kulliyyah of Architecture \& Environmental Design \\ INTERNATIONAL ISLAMIC UNIVERSITY MALAYSIA \\ ${ }^{2}$ Faculty of Environmental Studies \\ UNIVERSITI PUTRA MALAYSIA
}

\begin{abstract}
The paper focuses on the modelling attempt of willingness to pay for an improved bus service in selected cities and towns of Malaysia. Using responses from onboard intercept surveys, 1,130 samples of bus passengers have been analysed so as to arrive at a simplified model of how passengers trade off their money with possible upgrading of bus services elements. The willingness to pay among these bus riders was very low, despite the high expectation of improvements aspired by them. For service providers, fares are a function of travel time, travel distance and other operating costs. For passengers, the utility function is explained by costs, time, distance and various latent parameters. This paper highlights the significant results of chi-square analysis at various confidence levels. However, modelling the exact utility function of preferences for staggered increased in fares could not be carried out successfully at 95 percent confidence level, due to the relatively small number of respondents stating their and/or undecided response to willingness to pay for the additional fare rate. The issue of non-response to hypothetical survey questions is also raised, explaining the difficulties in modelling this choice behaviour.
\end{abstract}

Keyword: Public transport, bus, willingness to pay, frequency, increased fare.

Date Received: $30^{\text {th }}$ April 2016

Date of Acceptance: $30^{\text {th }}$ October 2016 
Syahriah Bachok, \& Zakiah Ponrahono

Modelling Willingness to Pay for Improves Public Transport Services: The Challenges of Non-Response to Stated Preference Hypothetical Questions

\section{INTRODUCTION}

Improvement of public transport services is essential in ensuring the maintenance of operation and sustenance of patronage. Among the less unattractive public transport provision is the bus service. Buses are more susceptible to congestion and incidents due to shared road spaces with other road users and vehicles, having no exclusive right of ways. For users, higher aspiration could be expected compared to rail and taxi services due to the lower comfort and convenience levels offered to bus passengers.

This paper elaborates on the passengers' expectation of improved bus services in various aspects. The case study presented in this paper is eight towns and cities in four Malaysian states of Johor, Pahang, Perak and Penang. The aim of the research is to model the willingness to pay for an increased fare rate among passengers for specific bus improvement areas. The objectives of the research are: i) to identify the socio-demographics of bus passengers in Malaysia, ii) to determine the proportion of passengers willing to pay additional fare in return of improved bus services and iii) to develop simplified model explaining such willingness.

\section{BUS FARES AND WILLINGNESS TO PAY}

Contemporary literature has been focusing on improvement of buses in various aspects of the services. The focus of this paper, is however, limited to the determination and structuring of the fare system. Basic fare system which concentrated on time and distance costs has been discussed by Turvey and Mohring (1975), and Pedesson (2003). The utility function for fare structure, has been globally set to be consisting of travel time which include both in-vehicle time and waiting time, travel distance and seating capacity.

Other factors or parameters found to be significant in determining the fare amount and structure are fleet supply or vehicular interior configuration, as well as fuel type and utilisation rate. Among these studies, O'Garra et al., (2007), Ricci, Bellaby and Flynn (2008), and Saxe, Folkesson and Alvfors (2007) have discussed the effects of fleet and vehicular aspects such as chassis, fuel, route capacity and seating or standing capacities on fare structure change.

Time variability, confidence in schedules and consistency in operation time, headways and frequency have been found to be significant in determining fare structure as propagated by Phanikumar and Maitra (2007), Hensher and Stanley (2003), Li, Hensher and Rose (2010), and Dodgson and Katsoulacos (1988).

Waiting and other support facilities and amenities are also essential in fare rate determination (Hess, Brown \& Shoup, 2004). Politis et al. (2010) argued that information provision and dissemination system are also important in influencing fare structure. Latent variables such as comfort and convenient are 
also deemed important in explaining the changes in fare structure and system (Espino, Roman \& De Ortuzar, 2006).

Most researches have been contemporary yet were not conducted in South East Asian context, let alone, in the Malaysian scenarios. Hence, it is timely and essential that such similar study be undertaken in the Malaysian context so as to assist operators, regulators and authorities relevant to the public transport sectors to understand better the local or domestic bus fare and market structure.

\section{METHODOLOGY}

The research has deployed on-board intercept survey upon some 1,130 samples from four different states in Malaysia, namely Johor, Pahang, Perak and Penang. By 2014, National Key Results Areas of the Malaysian public transportation have been almost completely undertaken, with various initiatives and bus improvement schemes being implemented.

During the survey, passengers on board bus vehicles were approached with questionnaire survey set to be completed and returned within the respective duration of the bus trips. Questions were relating to socio-demographics, trip characteristics, perception of current or existing bus services, anticipation and aspiration of the future services and the hypothetical amount in fare increased given such anticipated improvement be implemented within stipulated time period.

Descriptive and inferential analyses have been conducted using SPSS version 23 software. The next section elaborates both analyses.

\section{FINDINGS AND DISCUSSION}

\section{Socio Demographics}

From the 1,130 samples, females were disproportionately represented, forming some 64 percent of bus passengers. With this gender bias distribution, it might be possible to expect some latent variables, including safety, security, comfort and convenience to be essential in explaining their responses, perception and choice behaviours. Figure 1 below shows the unequal distribution of age range, with higher representation (more than 30 percent) of young (20 to 30 years old) in the sample. So, it can be expected that aspiration of a modernised or state-of-the-art bus technologies are on the high. It can also be assumed that the samples represented users with a lower level of education, lower income earned and higher proportion of income being allocated and spent on transportation. Hence, willingness to pay for additional fare towards bus improvements can be expected to be relatively lower. 
Syahriah Bachok, \& Zakiah Ponrahono

Modelling Willingness to Pay for Improves Public Transport Services: The Challenges of Non-Response to Stated Preference

Hypothetical Questions

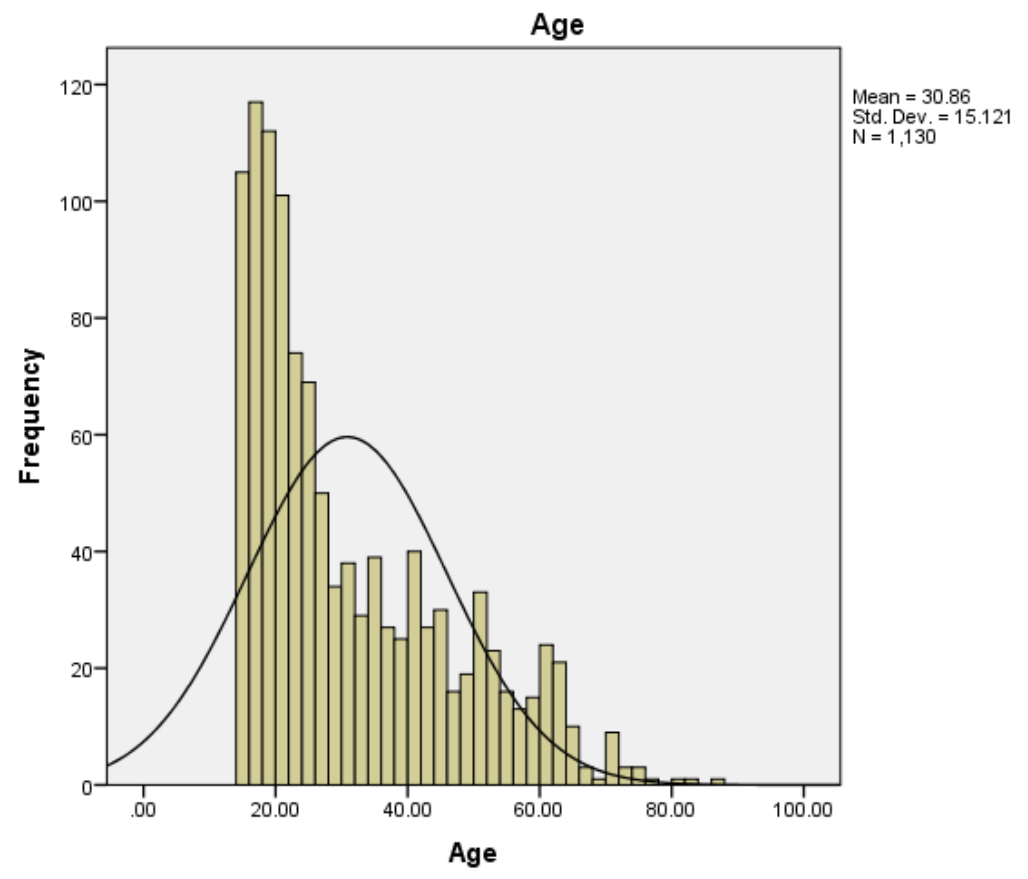

Figure 1 Respondents' Age Range

\section{Trip Characteristics}

Rides for leisure (43 percent) and commuting (38 percent) purposes on the bus were in the majority. The answers relating to fare would be expected to be very elastic because of the leisurely nature of the trips made.

Table 1 Respondents' Trip Purpose

\begin{tabular}{|l|c|c|}
\hline & Frequency & Percent \\
\hline Business & 47 & 4.2 \\
Educational & 167 & 14.8 \\
Leisure & 490 & 43.4 \\
Workplace & 426 & 37.7 \\
Total & 1130 & 100.0 \\
\hline
\end{tabular}

About 40 percent of respondents were using the buses less than 5 days per month. In other words, they were infrequent bus riders. About 18 percent were regular passengers, using the buses almost on daily basis (more than 20 days in a month). Hence, the answers relating to fare would be expected to be very elastic due to the non-frequent usage of the bus services. 
PLANNING MALAYSIA:

Journal of the Malaysia Institute of Planners (2017)

Table 2 Respondents' Current Monthly Trip Frequency

\begin{tabular}{|l|l|l|}
\hline & Frequency & Percent \\
\hline less than 5 days per month & 452 & 40.0 \\
6-10 days per month & 69 & 6.1 \\
11-15 days per month & 113 & 10.0 \\
16-20 days per month & 296 & 26.2 \\
21-25 days per month & 86 & 7.6 \\
more than 26 days per month & 114 & 10.1 \\
Total & 1130 & 100.0 \\
\hline
\end{tabular}

\section{Bus Conditions and Improvements Aspired}

In general, passengers surveyed were dissatisfied (60 percent) with the current bus services, reflecting the possibility of lower willingness to pay for increased rate of fare. These passengers had already had negative perception of the quality of services provided and would not be in favour of any price increase. This is further supported by the list of improvements aspired by the respondents. Most remarks (31 percent) were made on punctuality, frequency, departure and arrival time. Next, they would prefer clean and comfortable vehicles (17 percent) and new or modern vehicles (10 percent). It can be said that, expectation was high of the current quantity and quality of vehicle fleet. Waiting facilities were also of great concern ( 7 percent). Affordability ( 6 percent) however, received less than proportionate attention by the respondents. Information provision and safety or security issues were also ranked lower by respondents (4 percent, respectively). Some 19 percent users did not respond to this question. It is quite common that survey of this nature to receive non-preference feedback as discussed by various authors (Sanchez \& Morchio, 1992; Duffy \& Smith, 2005). Refer Table 3 and Table 4 below.

Table 3 Respondents' Satisfactory Level with the Existing Bus Services

\begin{tabular}{|l|c|c|}
\hline & Frequency & Percent \\
\hline Dissatisfied & 682 & 60.4 \\
Between Satisfied and Dissatisfied & 242 & 21.4 \\
Satisfied & 206 & 18.2 \\
Total & 1130 & 100.0 \\
\hline
\end{tabular}

Table 4 Respondents' Aspiration of Aspect of Bus Services to be Improved

\begin{tabular}{|l|l|l|}
\hline & Frequency & Percent \\
\hline On-time service and more frequent & 353 & 31.2 \\
Reliable and accurate information & 54 & 4.8 \\
Comfort and clean vehicles & 195 & 17.3 \\
Safe and Secure service & 47 & 4.2 \\
Affordable service & 70 & 6.2 \\
New vehicle and modern system & 115 & 10.2 \\
New waiting facilities and infrastructure & 80 & 7.1
\end{tabular}


Syahriah Bachok, \& Zakiah Ponrahono

Modelling Willingness to Pay for Improves Public Transport Services: The Challenges of Non-Response to Stated Preference Hypothetical Questions

No comment or positive comment for current service Total

\begin{tabular}{l|l}
216 & 19.1
\end{tabular} $1130 \quad 100.0$

Respondents were also asked about other preferences. The stated preference for frequency of use can be seen almost equally distributed (between 16 percent and 25 percent). Lower responses (12 percent) were gained for "never" to ride the bus again. The majority (41 percent) would prefer buses to operate between $6 \mathrm{am}$ and $10 \mathrm{pm}$, which was a fairly appropriate service duration for a typical bus service. However, a high majority (62 percent) would like to see a more frequent service in the future, with buses arriving or departing every 15 minutes. This reflected the invariability of bus frequency that the respondents were experiencing, disclosing the issue of punctuality and headways. The speed at which most respondents (37 percent) preferred was that bus operating at $70 \mathrm{~km}$ per hour. Refer Table 5, Table 6, Table 7 and Table 8 below.

Table 5 Respondents' Stated Preference of Trip Frequency if Bus Services are Improved

\begin{tabular}{|l|l|l|}
\hline & Frequency & Percent \\
\hline everyday & 260 & 23.0 \\
5 days per week & 276 & 24.4 \\
3 day per week & 182 & 16.1 \\
1 day per week & 278 & 24.6 \\
never & 134 & 11.9 \\
Total & 1130 & 100.0 \\
\hline
\end{tabular}

Table 6 Respondents' Stated Preference of Bus Service Duration

\begin{tabular}{|l|l|l|}
\hline & Frequency & Percent \\
\hline 9.00am to $6.00 \mathrm{pm}$ & 243 & 21.5 \\
$6.00 \mathrm{am}$ to $9.00 \mathrm{pm}$ & 134 & 11.9 \\
$6.00 \mathrm{am}$ to $10.00 \mathrm{pm}$ & 458 & 40.5 \\
$8.00 \mathrm{am}$ to $11.00 \mathrm{pm}$ & 210 & 18.6 \\
$7.00 \mathrm{am}$ to $9.00 \mathrm{pm}$ & 85 & 7.5 \\
Total & 1130 & 100.0 \\
\hline
\end{tabular}

Table 7 Respondents' Stated Preference of Bus Frequency

\begin{tabular}{|l|l|l|}
\hline & Frequency & Percent \\
\hline every 60 minutes & 43 & 3.8 \\
every 45 minutes & 40 & 3.5 \\
every 30 minutes & 190 & 16.8 \\
every 20 minutes & 152 & 13.5 \\
every 15 minutes & 705 & 62.4 \\
Total & 1130 & 100.0 \\
\hline
\end{tabular}


PLANNING MALAYSIA:

Journal of the Malaysia Institute of Planners (2017)

Table 8 Respondents' Stated Preference of Bus Average Speed

\begin{tabular}{|l|l|l|}
\hline & Frequency & Percent \\
\hline $90 \mathrm{~km} / \mathrm{h}$ & 132 & 11.7 \\
$80 \mathrm{~km} / \mathrm{h}$ & 220 & 19.5 \\
$70 \mathrm{~km} / \mathrm{h}$ & 423 & 37.4 \\
$60 \mathrm{~km} / \mathrm{h}$ & 228 & 20.2 \\
$45 \mathrm{~km} / \mathrm{h}$ & 127 & 11.2 \\
Total & 1130 & 100.0 \\
\hline
\end{tabular}

When posed with issues of priority improvements, respondents ranked high aspects related to safety and waiting facilities (29 percent). However, combined together (43 percent), issues relating to travel time, frequency and punctuality were deemed important too (Table 9).

Table 9 Respondents' Stated Preference of Prioritised Area Public Transport Improvement

\begin{tabular}{|l|l|l|}
\hline & Frequency & Percent \\
\hline on time & 235 & 20.8 \\
frequent & 255 & 22.6 \\
safe and facilitate with proper bus stop & 331 & 29.3 \\
clean and comfort & 210 & 18.6 \\
trained and competent driver & 99 & 8.8 \\
Total & 1130 & 100.0 \\
\hline
\end{tabular}

A hypothetical scenario relating to fare increased in return for better and improved services was received with mixed responses. Table 10 below indicates passengers surveyed perceived that safety, comfort and cleanliness (30 percent) were the stronger aspects to be prioritised if fare was to be increased. This was followed by provision of wifi and television on board ( 25 percent), quality drivers (17 percent), fully seated vehicles and electronic fare system (14 percent respectively).

Table 10 Respondents' Stated Preference of Bus Services Aspects, if They Have to Pay Increased Fare Rate

\begin{tabular}{|l|l|l|}
\hline & Frequency & Percent \\
\hline trained and competent driver & 188 & 16.6 \\
safe, comfort and clean bus & 337 & 29.8 \\
provide wifi and tv & 283 & 25.0 \\
no standing passengers & 162 & 14.3 \\
electronic ticketing system & 160 & 14.2 \\
Total & 1130 & 100.0 \\
\hline
\end{tabular}


Syahriah Bachok, \& Zakiah Ponrahono

Modelling Willingness to Pay for Improves Public Transport Services: The Challenges of Non-Response to Stated Preference Hypothetical Questions

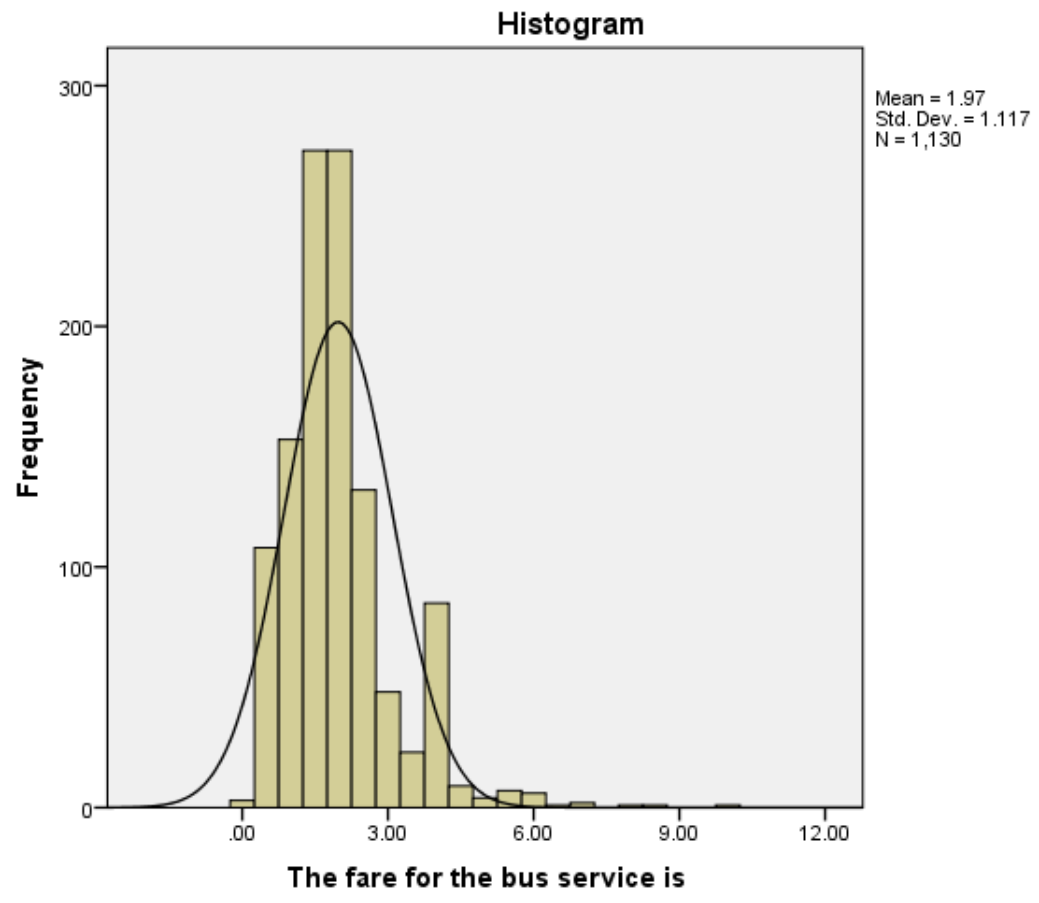

Figure 2 The Distribution of Ranges of Current Fare Paid Respondents

Current fare ranges paid by respondents was from RM0.00 to RM10.00 (Figure 2). Half of respondents (50 percent) paid between RM2.01 and RM3.00. Some 20 percent paid RM1 and less. This was followed by those who paid between RM3.01 and RM4.00 (17 percent). About 10 percent paid between RM4.01 and RM5.00. The remainder (3 percent) paid between RM5.01 and RM10.00.

When hypothetical questions relating to willingness to pay, only 64 respondents or less than 6 percent stated positive reactions (Table 11). Issues of lower responses for willingness to pay questions and their parameters have been discussed by many authors including Lui and Jansen (2017), Martinez-Espiniera and Lyssenko (2012), Manisera and Zuccolotto (2014), Gibbs Jr. and Bryant (2008) and Lietz (2008). These authors discussed the effects of social desirability, political correctness, cognitive effects and efforts, optimal relevance and attitude as hindrances to extraction of exact responses for hypothetical questions. This was especially true of questions relating to monetary, finance and fiscal elements relating to respondents' personal income and expenditure. Due to this negative reception of willingness to pay questions, it has been a challenge for the authors of this paper to develop and determine the most suitable model to reflect this choice behaviour. 
PLANNING MALAYSIA:

Journal of the Malaysia Institute of Planners (2017)

Table 11 Respondents' Stated Preference of Future Increased in Fare

\begin{tabular}{|ll|l|l|}
\hline & Frequency & Percent \\
\hline Valid & maintain current fare & 1066 & 94.3 \\
& increase 10-20cent & 40 & 3.5 \\
increase 30-40cent & 16 & 1.4 \\
increase 50-60cent & 8 & .7 \\
Total & 1130 & 100.0 \\
\hline
\end{tabular}

\section{Willingness to Pay for Additional Fare}

This section elaborates the stated preference for increased fare rate. It discusses the attempts at modelling this preferential behaviour.

Table 12 Fare Increased Preferred by Respondents Willing to Pay for Increased Fare

\begin{tabular}{|ll|l|l|}
\hline & Frequency & Percent \\
\hline Valid & increase 10-20cent & 40 & 62.5 \\
& increase 30-40cent & 16 & 25.0 \\
& increase 50-60cent & 8 & 12.5 \\
& Total & 64 & 100.0 \\
\hline
\end{tabular}

Table 12 above, indicates that only 64 users surveyed preferred fare increase at various levels to be paid for improvement of bus services. The majority (63 percent) were willing to spend some RM0.20 for this purpose. A quarter (25 percent) were willing to pay additional RM0.40 to see bus improvements in the near future. For the 6 percent respondents who were willing to pay additional fare in return for improved bus services, the followings are the aspects of bus improvements they would like to see in the near future (Table 13).

Table 13 Bus frequency Preferred by Respondents Willing to Pay for Increased Fare

\begin{tabular}{|ll|l|l|}
\hline & Frequency & Percent \\
\hline Valid & every 60 minutes & 2 & 3.1 \\
& every 30 minutes & 9 & 14.1 \\
every 20 minutes & 7 & 10.9 \\
every 15 minutes & 46 & 71.9 \\
Total & 64 & 100.0 \\
\hline
\end{tabular}

For the fare increased, the majority ( 72 percent) would prefer to have bus service at every 15 minutes or 4 buses in an hour (Table 13). Other non-time related improvements were comfort (33 percent) and safety ( 23 percent). Refer Table 14 below. 
Syahriah Bachok, \& Zakiah Ponrahono

Modelling Willingness to Pay for Improves Public Transport Services: The Challenges of Non-Response to Stated Preference

Hypothetical Questions

Table 14 Bus Improvement Priority Areas by Respondents Willing to Pay for Increased Fare

\begin{tabular}{|c|c|c|c|}
\hline \multirow{2}{*}{$\overline{\text { Valid }}$} & & Frequency & Percent \\
\hline & increase the safety & 15 & 23.4 \\
\hline & fix trip/schedule & 6 & 9.4 \\
\hline & on time trip & 8 & 12.5 \\
\hline & more frequent trip & 8 & 12.5 \\
\hline & waiting time less than $10-15 \mathrm{~min}$ & 5 & 7.8 \\
\hline & comfort (wifi, air-cond, etc.) & 21 & 32.8 \\
\hline & to remain the current fare & 1 & 1.6 \\
\hline & Total & 64 & 100.0 \\
\hline
\end{tabular}

\section{Modelling}

Inferential analysis for this study has been chi-square tests and a linear regression modelling for the willingness to pay additional fare. The following tables provide the analysis results.

Table 15 Chi-Square Cross Tabulation of Fare Choices (DV) * Reason to Increase Fare (IV)

\begin{tabular}{|l|c|c|c|}
\hline & \multicolumn{2}{|c|}{ Reason to increase fare collapse } & Total \\
\cline { 2 - 4 } & $\begin{array}{c}\text { Comfort safety and latent } \\
\text { parameters }\end{array}$ & $\begin{array}{c}\text { Travel time } \\
\text { parameters }\end{array}$ & \\
\hline increase 10-20cent & 21 & 19 & 40 \\
increase 30-40cent & 9 & 7 & 16 \\
increase 50-60cent & 7 & 1 & 8 \\
Total & 37 & 27 & 64 \\
\hline
\end{tabular}

Chi-Square Tests

\begin{tabular}{|l|l|l|l|}
\hline & Value & df & $\begin{array}{l}\text { Asymptotic Significance } \\
(2-\text {-sided })\end{array}$ \\
\hline Pearson Chi-Square & $3.370^{\mathrm{a}}$ & 2 & .185 \\
Likelihood Ratio & 3.844 & 2 & .146 \\
Linear-by-Linear Association & 2.554 & 1 & .110 \\
N of Valid Cases & 64 & & \\
\hline
\end{tabular}


PLANNING MALAYSIA:

Journal of the Malaysia Institute of Planners (2017)

Symmetric Measures

\begin{tabular}{|ll|l|l|}
\hline & & & $\begin{array}{l}\text { Approximate } \\
\text { Significance }\end{array}$ \\
\hline Nominal by Nominal & Phi & Value & .229 \\
& Cramer's V & .229 & .185 \\
& Contingency Coefficient & .224 & .185 \\
N of Valid Cases & & 64 & \\
\hline
\end{tabular}

From the three tables above, results have shown that willingness to pay for additional fare were not significantly different for those users who preferred improvements in latent variables (comfort and safety) compared to those preferring travel-time related variables. At 95\% confidence level, p-value was 0.185 (higher than critical 0.05) and Phi and Cramer's V values were small (0.229), indicating a failure to reject the null hypothesis.

Another attempt at explaining the willingness to pay additional charge was upon the headways of bus in an hour. The three tables below, show that bus headways or frequency in an hour had been significant in explaining the difference in fare increased preferred by users surveyed. The results of $p$-value at 0.045 and slightly higher Phi and Cramer's V value of 0.312 , indicated a significant relationship between fare rate increase and bus frequency. In other words, passengers who were positive about additional fare would consider paying more for increased bus frequency or reduced headways.

Table 16 Chi-Square Cross Tabulation of Fare Choices (DV) * Preferred Bus Frequency (IV)

\begin{tabular}{|ll|cc|l|}
\hline & & \multicolumn{2}{|l|}{ Preferred frequency } & \\
& & 1 & 4 & Total \\
\hline Fare choices & increase 10-20cent & 4 & 36 & 40 \\
& increase 30-40cent & 6 & 10 & 16 \\
Total & increase 50-60cent & 1 & 7 & 8 \\
& & 11 & 53 & 64 \\
\hline
\end{tabular}

Chi-Square Tests

\begin{tabular}{|l|l|l|l|}
\hline & & & \multicolumn{1}{c|}{ Asymptotic } \\
& Value & df & Significance (2-sided) \\
\hline Pearson Chi-Square & $6.213^{\mathrm{a}}$ & 2 & .045 \\
Likelihood Ratio & 5.527 & 2 & .063 \\
Linear-by-Linear Association & 1.351 & 1 & .245 \\
N of Valid Cases & 64 & & \\
\hline
\end{tabular}


Syahriah Bachok, \& Zakiah Ponrahono

Modelling Willingness to Pay for Improves Public Transport Services: The Challenges of Non-Response to Stated Preference

Hypothetical Questions

Symmetric Measures

\begin{tabular}{|c|c|c|c|}
\hline & & Value & $\begin{array}{l}\text { Approximate } \\
\text { Significance }\end{array}$ \\
\hline $\begin{array}{l}\text { Nominal by Nominal } \\
\mathrm{N} \text { of Valid Cases }\end{array}$ & $\begin{array}{l}\text { Phi } \\
\text { Cramer's V } \\
\text { Contingency Coefficient }\end{array}$ & $\begin{array}{l}.312 \\
.312 \\
.297 \\
64\end{array}$ & $\begin{array}{l}.045 \\
.045 \\
.045\end{array}$ \\
\hline
\end{tabular}

Next, a simple linear regression was carried out to model the willingness to pay for increased fare, in the attempt at predicting the value for money of these respondents. The following four tables can be summarised to represent a significant model at 90 percent confidence level, with fare rate increased being positively determined by the increased in bus frequency or reduced headways (albeit lower $\mathrm{R}^{2}=0.049$ and $\mathrm{p}$-value of 0.080 ). The derived utility function would be as follows: Fare increased $=\mathrm{RM} 0.18+0.347$ (hourly bus frequency)

Table 17 Regression Analysis for Variables Entered/Removed

\begin{tabular}{|l|l|l|l|}
\hline Model & Variables Entered & Variables Removed & Method \\
\hline 1 & Preferred frequency & & Enter \\
\hline
\end{tabular}

a. Dependent Variable: Fare choices

b. All requested variables entered.

Table 18 Model Summary

\begin{tabular}{|l|l|l|l|l|}
\hline Model & $\mathrm{R}$ & R Square & Adjusted R Square & Std. Error of the Estimate \\
\hline 1 & $.221^{\mathrm{a}}$ & .049 & .033 & 14.014 \\
\hline
\end{tabular}

a. Predictors: (Constant), preferred frequency

Table 19 ANOVA $^{\mathrm{a}}$

\begin{tabular}{|c|c|c|c|c|c|c|}
\hline Model & & $\begin{array}{c}\text { Sum of } \\
\text { Squares }\end{array}$ & df & Mean Square & $\mathrm{F}$ & Sig. \\
\hline 1 & $\begin{array}{l}\text { Regression } \\
\text { Residual } \\
\text { Total }\end{array}$ & $\begin{array}{l}623.827 \\
12176.173 \\
12800.000\end{array}$ & $\begin{array}{l}1 \\
62 \\
63\end{array}$ & $\begin{array}{l}623.827 \\
196.390\end{array}$ & 3.176 & $.080^{\mathrm{b}}$ \\
\hline
\end{tabular}

a. Dependent Variable: Fare choices

b. Predictors: (Constant), preferred frequency

Table 20 Coefficients $^{\mathrm{a}}$

\begin{tabular}{|l|c|c|c|l|l|}
\hline \multirow{2}{*}{ Model } & \multicolumn{2}{|c|}{$\begin{array}{c}\text { Unstandardized } \\
\text { Coefficients }\end{array}$} & $\begin{array}{c}\text { Standardized } \\
\text { Coefficients }\end{array}$ & \multirow{2}{*}{$\mathrm{t}$} & \multirow{2}{*}{ Sig. } \\
\cline { 2 - 7 } & $\mathrm{B}$ & Std. Error & Beta & & .000 \\
\hline (Constant) & 18.394 & 4.100 & & 4.486 & .000 \\
\hline
\end{tabular}

a. Dependent Variable: Fare choices 
PLANNING MALAYSIA:

Journal of the Malaysia Institute of Planners (2017)

\section{RECOMMENDATIONS AND CONCLUSION}

This paper has discussed the perception of 1,130 bus passengers on the current bus services in four Malaysian states. From the analysis, the users surveyed had generally negative views on the existing service provision. They were highly aspired to see more improvements on buses services, especially in the following aspects: travel time, waiting time, punctuality and bus frequency. Also receiving attentions were issues of safety, comfort and vehicles quality. Hence, these are priority areas that bus operators, vehicle suppliers, transport regulators and monitoring authorities and respective agencies related to public transport must be focusing on, when initiating pilot improvement schemes or investing in the future public transport systems.

When hypothetically faced with increase fare rates, preferences were clearly skewed towards increased frequency or reduced headways compared to other latent variables. The paper has attempted at modelling and predicting the necessary improvements in bus services, especially with regards to frequency, when the inevitable price or fare increase is to be executed by public transport operators or regulators.

All three objectives of the papers, including determining the proportion of passengers willing to pay additional fare amount in return of improved bus services, and developing a model explaining such willingness have been achieved. It is therefore concluded that, public transport passengers were willing to pay for additional fare, provided that service frequency was to be increased. This paper confirms findings of previous research by Hensher and Rose (2010), and Phanikumar and Maitra (2007). The findings were also in congruent with previous on issues faced by hypothetical questionnaire types of data collection methodology, whereby high proportion of respondents were not willing to help in determining prices or monetary values even if they possessed the expertise and experiences to answer these questions types as propagated by Sanchez \& Morchio (1992), Lietz and Petra (2008) and Duffy and Smith (2005).

\section{REFERENCES}

Dodgson, J. S. \& Katsoulacos, Y. (1988). Quality competition in bus services: some welfare implications of bus deregulation. Journal of Transport Economics and Policy, 22(3), 263-281.

Duffy, B., \& Smith, K. (2005). Comparative data from online and face-to-face surveys. International Journal of Market Research, 47(6), 615-639.

Espino, R., Roman, C., \& De Ortuzar, J. D. (2006). Analysing demand for suburban trips: a mixed $\mathrm{rp} / \mathrm{sp}$ model with latent variables and interaction effects. Transportation, 33(3), 241-261.

Gibbs Jr., R. W., \& Bryant, G. A. (2008). Striving for optimal relevance when answering questions. Cognition, 106, 345-369.

Hensher, D. A., \& Stanley, J. (2003). Performance-based quality contacts in bus service provision. Transportation Research Part A: Policy and Practice, 37(6), 519-538. 
Syahriah Bachok, \& Zakiah Ponrahono

Modelling Willingness to Pay for Improves Public Transport Services: The Challenges of Non-Response to Stated Preference Hypothetical Questions

Hess, D. B., Brown, J., \& Shoup, D. (2004). Waiting for the bus. Public Transportation, 7(4), 67-84.

Li, Z., Hensher, D. A., \& Rose, J.M. (2010). Willingness to pay for travel time reliability in passenger transport: A review and some new empirical evidence. Transportation Research Part E: Logistics and Transportation Review, 46(3), 384-403.

Lietz, P. (2008). Questionnaire design in attitude and opinion research: current state of an art (655 Working Paper), Jacobs University, Bremen.

Liu, Z., \& Jansen, B. J. (2017). Identifying and Predicting the Desire to Help in Social Question and Answering. Information Processing and Management, 53, 490-504.

Manisera, M., \& Zuccolotto (2014). Modelling "Don't Know" Responses in Rating Scales. Pattern Recognition Letters, 45, 226-234.

Martinez-Espineira, R., \& Lyssenko, N. (2012). An alternative approaches to dealing with respondent uncertainty in contingent valuation: a comparative analysis. Journal of Environmental Management, 93, 130-139.

O’Garra, T., Mourato, S., Garrity, L. et al. (2007) Is the public willing to pay for hydrogen buses: a comparative study of preference in four cities. Energy Policy, 35(7), 36303642.

Phanikumar, C. V., \& Maitra, B. (2007). Willingness to pay and preference heterogeneity for rural bus attributes. Journal of Transportation Engineering, 133(1), 62-69.

Pedesson, P. A. (2003). On the optimal fare policies in urban transportation. Transportation Research Part B: Methodological, 37(5), 423-435.

Politis, I., Papaioannou, P., Basbas, S., \& Dimitriadis, N. (2010). Evaluation of a bus passenger information system from the users' point of view in the city of Thessaloniki, Greece. Research in Transportation Economics, 29(1), 249-255.

Ricci, M., Bellaby, P., \& Flynn, R. (2008). What do we know about public perceptions and acceptance of hydrogen bus? A critical review and new case study evidence. International Journal Hydrogen Energy, 33(21), 5868-5880.

Sanchez, M. E., \& Morchio, G. (1992). Probing "don't know" answers effects on survey estimates and variables relationships. Public Opinion Quarterly, 56, 454-474.

Saxe, M., Folkesson, A., \& Alvfors, P. (2007). A follow up and conclusive report on the attitude towards hydrogen fuel cells buses in the cute project - from passengers in Stockholm to bus operators in Europe. International Journal of Hydrogen Energy, 32(7), 4295-4305.

Turvey, R., \& Mohring, H. (1975). Optimal bus fares. Journal of Transport Economics and Policy, 9(3), 280-286. 